\title{
Socioenvironmental factors and behaviors associated with negative self-rated health in Brazil
}

\author{
Fatores socioambientais e comportamentos associados \\ à percepção negativa de saúde no Brasil
}

Geraldo Jose Ferrari Junior (https://orcid.org/0000-0002-9739-3220) ${ }^{1}$

Clarissa Stefani Teixeira (https://orcid.org/0000-0003-1362-1255) ${ }^{2}$

Érico Pereira Gomes Felden (https://orcid.org/0000-0002-6924-122X) ${ }^{1}$

${ }^{1}$ Centro de Ciências da Saúde e do Esporte, Universidade do Estado de Santa Catarina. R. Pascoal Simone 358, Coqueiros. 88080-350 Florianópolis SC Brasil.geraldo_ferrari@ hotmail.com

${ }^{2}$ Universidade Federal

de Santa Catarina.

Florianópolis SC Brasil.

\begin{abstract}
The purpose of this study is to determine the factors associated with negative self-rated health in Brazil. The sample consisted of 5,259 adults from five representative capitals of the five regions of Brazil. Data collection was achieved in the following municipalities: Palmas (North Region), João Pessoa (Northeast Region), Goiânia (Central-West Region), Vitória (Southeast Region) and Florianópolis (South Region). For the analysis of the data, Binary Logistic Regression for determine the factors associated with negative self-rated health was used. Negative self-rated health was identified in $31.43 \%$ of Brazilians. The factors that were significantly associated were bad air quality, does not have public spaces for leisure, older age group, insufficient salary to cover expenses, a rare practice of physical exercises, does not perform healthy eating, active commuting for study or employment and commuting time for above 30 minutes, dissatisfaction with health services and still, not working, not looking for a job and finally, reside in some Brazilian regions. The study presents the importance of socioenvironmental and behavioral factors for the self-rated health of Brazilian adults, as well as it shows high rates of negative self-rated health compared to other studies.
\end{abstract}

Key words Brazil, Self-rated health, Exercise, Active transport, Health behavior
Resumo O objetivo deste estudo foi determinar os fatores associados à percepção negativa de saúde no Brasil. A amostra foi composta por 5.259 adultos de cinco capitais representativas das cinco regiões do Brasil. A coleta de dados foi realizada nos seguintes municípios: Palmas, João Pessoa, Goiânia, Vitória e Florianópolis. Para analisar os dados, utilizou-se da Regressão Logística Binária para determinar os fatores associados. Identifcou-se percepção negativa de saúde em 31,43\% dos brasileiros. Os fatores que foram significativamente associados foram: má qualidade do ar, não possuir espaços públicos de lazer, faixa etária mais avançada, salário insuficiente para cobrir despesas, prática rara de exercícios físicos, não realizar alimentação saudável, deslocamento ativo para estudo ou emprego, tempo de deslocamento acima de 30 minutos, insatisfação com os serviços de saúde, não trabalhar e não estar procurando emprego e, por fim, residir nas regiões Sul, Sudeste e Nordeste do Brasil. O estudo apresenta a importância de fatores socioambientais e comportamentais para a percepção da saúde de adultos brasileiros e mostra altos indices de percepção negativa de saúde em comparação com outros estudos.

Palavras-chave Brasil, Autoavaliação de saúde, Exercício, Transporte ativo, Comportamento em saúde 


\section{Introduction}

Self-assessment of health is a measure that expresses the general health condition, is considered a critical aspect of individual well-being ${ }^{1}$ and has been widely used in public health ${ }^{2}$. Besides, it is frequently referred to as a predictor of mortality ${ }^{3-5}$ and was recommended as a standard measure in health research with a large population ${ }^{6}$.

The interest in research on the health of large populations is growing in several countries and comes from the need to understand how different factors affect health.In this perspective, the studies point to some relevant factors when analyzing people's self-rated health's such as health limitations ${ }^{7,8}$, lifestyle 9 , physical and social environment $^{7,10-12}$, sociodemographic ${ }^{11}$ and individual circumstances ${ }^{9,13}$. Besides, studies in developing African country ${ }^{14,15}$ have presented other factors, such as age, sex, and individual health behaviors that may contribute negatively to health.

These previous investigations allowed the reflection of theoretical models to a better understanding of what is associated with the negative self-rated health of adults. In general, models comprise a hierarchy of proximal (individual, behavioral or material), intermediate (sociodemographic, socioenvironmental or psychosocial) and distal (contextual) $)^{2,4,16,17}$. Also, the recent review by Moor et al. ${ }^{2}$ reports greater importance of factors of material/structural (proximal) living conditions for the explanation of self-rated health due to its more significant direct (indirect) and shared (indirect) effect by psychosocial and behavioral factors.

Thus, adapting the models to the Brazilian reality, new variables based on this model can be investigated in order to contemplate a greater understanding of the influences on the self-rated health of adults in Brazil. Besides, the methodological and design differences in the previous studies and the disparity between the realities of the American, European and African peoples with that of the Brazilians indicate that new research in Brazilian territory can contribute to the discussion of the influence of cultural, contextual, socioenvironmental and behavioral ${ }^{3,18}$. For this, the present study purposeof determiningthe factors associated with negative self-rated health in Brazil.

\section{Method}

\section{Data}

This research was carried out by the citizen monitoring network entitled "See the City" (Ver a Cidade), an independent and nonpartisan organization, using the methodology of "Emerging and Sustainable Cities Program (ESC)" of the Inter-American Development Bank (IDB), entitled Public Opinion Survey (Pesquisa de Opinião Pública - POP), which seeks to monitor, technically and impartially, the performance of the city in specific indicators that impact on the sustainability and quality of life of its citizens. The data were collected in October of 2017 in five capitals, one in each Brazilian region: Palmas (North), João Pessoa (Northeast), Goiânia (Central-West), Vitória (Southeast) and Florianópolis (South). For each city, a sample calculation was performed, aiming at a representative Brazilian sample. This study is a descriptive and observational epidemiological of a transverse nature by sampling. Furthermore, it conforms with the principles contained in the Declaration of Helsinki.

\section{Sample}

For data collection, the subjects were randomly approached on the streets, in predetermined subdistricts, in each city investigated. For the sampling process, these sub-districts were defined by geostatistical sampling planning considering the population density and income of the neighborhoods to ensure sample representation with the adequate socioeconomic distribution. Thus, for the cartographic representation of the clusters, we used the survey of information of the spatial data of the municipality (for assembly of the cartographic base) and survey of socioeconomic data of the city based on the 2010 Census conducted by the Brazilian Institute of Geography and Statistics (IBGE).

The criterion for selecting the cities considered a population smaller than 2 million, and that demonstrated emergent prosperity with development with sustainable. The sampling was aimed at the representativeness of adults (over 18 years old), residents of the cities participating in the research.

Criteria of Levine et al. ${ }^{19}$ for sample calculation were adopted. All cities presented four geostatistical groupings; thus, a minimum sample was calculated to be collected in each group con- 
sidering the calculation for finite populations ${ }^{19}$, with a sampling error of $6.2 \%$, proportion/ prevalence of the $50 \%$ outcome and $95 \%$ level of confidence. In total, the population of the five capitals investigated amounted to 3,070,039 inhabitants, being the minimum sample collected 5,259 Brazilian adults.

\section{Indicators}

The present study used in a standardized way the Emerging and Sustainable Cities Program methodology (ESC) ${ }^{20}$. This methodology and the same questionnaire were applied in 21 countries and 52 cities in Latin America and the Caribbean (with adequate adaptation/translation from Spanish to Portuguese). The structure of the questionnaire is divided into 24 thematic blocks with 165 questions focused on three dimensions: Environmental Sustainability and Climate Change, Urban Sustainability, and Fiscal Sustainability and Governance.The questionnaire was previously tested in the city of Vitória-ES, with five individuals from the highest income neighborhood and seven subjects from the lower-income neighborhood, thus identifying the understanding of the issues in the different profiles, averaging 50 minutes in duration of the questionnaire. This stage contributed to the planning of the field teams, production, adjustment in the questionnaire, and creation of cards (auxiliary instrument to the questionnaire). The questionnaire seeks direct public opinion on water conditions, sewage, solid waste, energy, air quality, noise, climate change and natural disasters, drainage, quality of public spaces in its region, health, safety, education, among other subjects. For the present research, sociodemographic, environmental, behavioral, and health issues were used.

The investigated sociodemographic variables were gender (male, female), age (18-34, 35-59, over 59 years), for the schooling were grouped as "Basic" (Elementary Education Incomplete, Complete and incomplete high school education), "High School" (high school and incomplete and college Incomplete) and "Superior/ post" (complete higher education, incomplete and complete graduate). The income was verified by the monthly income based on the minimum salary in force in 2017, that is, $\mathrm{R} \$ 937.00$ (in real) or \$ 249.15 (in dollars), of all who work and live in the same residence. For purposes of analysis, the values were grouped in "Low" (up to 2 minimum wages), "Medium" (More than 2 to
5 minimum wages), and "High" (More than five minimum wages). For the investigation of the variable Salary covers expenses, was asked "Does the salary, or payment, that you receive and the total family income allow you to cover your family needs satisfactorily? Which of these situations do you find yourself?". And answers are grouped in "Yes" (Fits well, we can save, cover expenses) and "No" (They do not cover all the expenses, we have difficulties, they do not cover all expenses, we have great difficulties). Still, the occupation was questioned, and the answer could be "Working", "Looking for work" and "Neither".

The environmental and behavioral variables investigated were the air quality, by the question "How do you generally classify the quality of the air you breathe when you move around your neighborhood?", and the answers were grouped in "Good" (Great, good), "Regular" (Regular) and "Bad" (Bad, poorly). For public spaces for leisure was questioned "Does your neighborhood have public spaces for leisure (parks, squares, public walks, sports courts, beaches, etc.)?", with yes or no answers. Regarding the afforestation in the neighborhood, it was asked, "Do you consider the streets in your neighborhood have trees?", the answers were grouped in "Many" (Many trees, Not many, not few trees) and "Few" (Very few trees; not have trees). The commuting time for the main activity was investigated through the question "On average, how long does it take you to go from your home to the place of your main activity (work, place of study, or other activity that you do most often)?", with the responses grouped under "Below $19 \mathrm{~min}$ " (Up to $10 \mathrm{~min}$; 11-19 sec), “20-29 min” (20-29 min) and "Over 30 min" (30 to 59 min, 1 hour, more than 1 hour). Also, the habitual type of commuting for this main activity was questioned, characterizing as active commuting those who answered "Bicycle" or "On foot" and passive individuals who answered "Bus, Car, Motorcycle, Moto-taxi or Taxi/ Uber/individual public transport”.

Besides, the practice of physical exercise, through the question "Do you practice physical exercises?" presented answers grouped in "Little" (Never, Rarely), Regular (Sometimes), and Very (Quite, Always). Regarding the perception of consumption of healthy foods, it was asked: "Do you consider that you eat well, in a healthy way?", with answers grouped as "Does not perform" (Never, rarely), "Sometimes" (Sometimes), and "Performs" (Enough, Always). Satisfaction with the health service was investigated through the question "How satisfied are you with the 
health services you use?", it was considered a health service: the Unified Health System - SUS (free public health service in Brazil), health insurance for work, and private health insurance. Finally, the dependent variable stems from the question "In general, how would you describe his state of health today?", with answers grouped into "Good" (Great, good) and "Bad" (Regular, Bad, Poorly).

\section{Statistical analysis}

In the sampling, the tool used was the cluster analysis, which allowed classifying and creating groups with common characteristics. Descriptive statistics were used (average, standard deviation, frequency distribution). Furthermore, we found the odds ratios using the Binary Logistic Regression univariate model. The regression analysis of the multivariate-adjusted model considered variables with $\mathrm{p}<0.20$ according to the proposal by Maldonado and Greenland ${ }^{21}$ and inferential (chi-square and binary logistic regression multivariate). Binary logistic regression multivariate was used to verify possible associations between self-rated health and independent variables. A statistical significance level of $5 \%$ was adopted for statistical analyzes. All analyses were performed in The Statistical Package for Social Sciences (SPSS) software version 20.0.

\section{Results}

The sample consisted of 5,259 adults from all Brazilian regions, 1,023 from Florianópolis, 1,026 from Goiânia, 1,036 from João Pessoa, 1,010 from Palmas and 1,067 from Vitória. The majority of the sample were female $(53.1 \%)$, aged up to 59 years $(82.5 \%)$, who have completed basic education $(75.7 \%)$, middle income (36.5\%), had salaries covering expenses (74.1\%), presented public spaces for leisure in their neighborhoods (66.5\%), still neighborhoods that had many trees $(66.0 \%)$ and had good air quality (53.2\%), commuted from home to the main activity (workplace or study) in less than 19 minutes $(52.8 \%)$, being passively displaced $(76.9 \%)$, worked $(61.2 \%)$, practiced little physical activity $(37.2 \%)$ and reported having a healthy diet (52.1\%) (Table 1 ).

When analyzing the distribution of self-rated health, in Brazil, 31.4\% reported negative self-rated health, when grouped the regular perception, bad and poorly, reaching 1,644 adults with this
Table 1. Descriptive data of the sample.

\begin{tabular}{|c|c|}
\hline Variable & n (\%) \\
\hline \multicolumn{2}{|l|}{ Gender } \\
\hline Male & $2,464(46.9)$ \\
\hline Female & $2,795(53.1)$ \\
\hline \multicolumn{2}{|l|}{ Age group } \\
\hline 18 to 34 years & $2,143(40.7)$ \\
\hline 35 to 59 years & $2,197(41.8)$ \\
\hline More than 59 years & $919(17.5)$ \\
\hline \multicolumn{2}{|l|}{ Education } \\
\hline Basic & $1,470(28.4)$ \\
\hline High School & $2,451(47.3)$ \\
\hline Superior/Post & $1,246(24.3)$ \\
\hline \multicolumn{2}{|l|}{ Income } \\
\hline Low & $1,709(35.2)$ \\
\hline Medium & $1,774(36.5)$ \\
\hline High & $1,375(28.3)$ \\
\hline \multicolumn{2}{|l|}{ Salary covers expenses } \\
\hline Yes & $3,849(74.1)$ \\
\hline No & $1,346(25.6)$ \\
\hline \multicolumn{2}{|l|}{ Air quality } \\
\hline Good & $2,758(53.2)$ \\
\hline Regular & $1,468(28.3)$ \\
\hline Bad & $961(18.5)$ \\
\hline \multicolumn{2}{|l|}{ Public spaces for leisure } \\
\hline It has & $3,452(66.5)$ \\
\hline Does not have & $1,736(33.5)$ \\
\hline \multicolumn{2}{|l|}{ Trees in the neighborhood } \\
\hline Many & $3,441(66.0)$ \\
\hline Few & $1,775(34.0)$ \\
\hline \multicolumn{2}{|l|}{ Commuting time } \\
\hline Below 19 min & $2,564(52.8)$ \\
\hline From 20 to $29 \mathrm{~min}$ & $954(19.6)$ \\
\hline Above $30 \mathrm{~min}$ & $1,338(27.6)$ \\
\hline \multicolumn{2}{|l|}{ CommutingType } \\
\hline Active & $1,151(23.1)$ \\
\hline Passive & $3,821(76.9)$ \\
\hline \multicolumn{2}{|l|}{ Occupation } \\
\hline Working & $3,189(61.2)$ \\
\hline Looking for a job & $541(10.4)$ \\
\hline Neither & $1,478(28.4)$ \\
\hline \multicolumn{2}{|l|}{ Practice of physical exercise } \\
\hline Little & $1,948(37.2)$ \\
\hline Regular & $1,405(26.8)$ \\
\hline Very & $1,884(36.0)$ \\
\hline \multicolumn{2}{|l|}{ Healthy eating } \\
\hline Does not perform & $987(18.8)$ \\
\hline Sometimes & $1,522(29.1)$ \\
\hline Perform & $2,730(52.1)$ \\
\hline \multicolumn{2}{|l|}{ City residents } \\
\hline Goiânia (Central-West) & $1,023(19,5)$ \\
\hline Florianópolis (South) & $1,026(19,5)$ \\
\hline Palmas (North) & $1,036(19,7)$ \\
\hline Vitória (Southeast) & $1,107(21,0)$ \\
\hline João Pessoa (Northeast) & $1,067(20,3)$ \\
\hline
\end{tabular}

Source: Elaborated by the authors. 


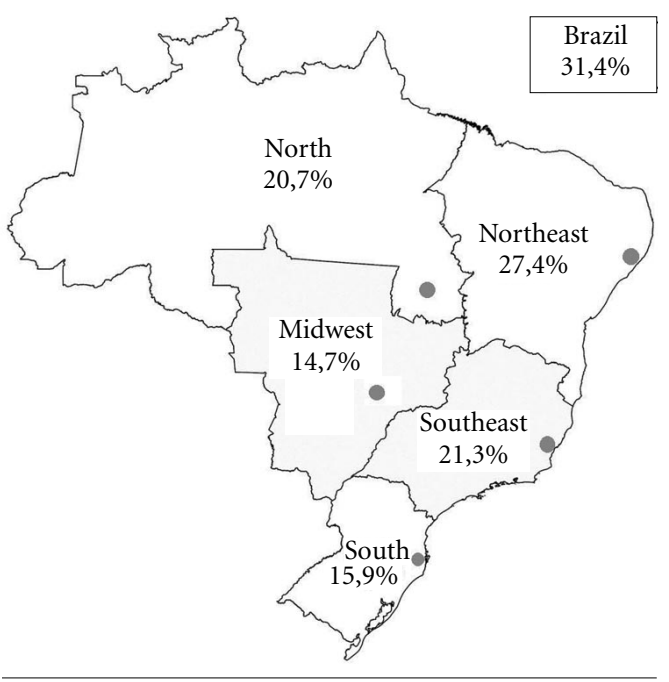

Figure 1. Distribution of negative self-rated health of adults in the five Brazilian regions and in the general sample.

Source: Elaborated by the authors.

perception (Figure 1). Still, it was observed that the Midwest was the region with the lowest prevalence of negative self-rated health (14.7\%). In contrast, the Northeast was the region with the highest prevalence of negative self-rated health (27.4\%).

The Odds Ratio (OR) investigated using as the dependent variable the negative self-rated health. In the univariate crude analysis, each variable was presented in Table 1. Among the variables, only the income did not reach the pre-established criterion of $\mathrm{p}<0.20$ to enter the adjusted analysis. The adjusted multivariate analysis showed several associations (Table 2).

Among socioeconomic variables, it was identified that those with salaries that did not cover their expenses and who did not work or did not study were $73 \%$ and $31 \%$, respectively, more likely to present negative perceptions of health compared to their peers. Still, how much older the more chances of negative self-rated health (Table 2).

Concerning the neighborhood that had poor air quality $(\mathrm{OR}=1.65 ; \mathrm{CI} 95 \%$ 1.36-2.01) and that did not have public leisure spaces $(\mathrm{OR}=1.18$; CI95\% 1.01-1.37) were more likely to report negative self-rated health (Table 2).
Thus, those commuting time for above 30 minutes $(\mathrm{OR}=1,31$; CI95\% 1,10-1,55) and who typically commuted actively (OR=1.36; CI95\% 1.14-1.62) were more likely to have negative self-rated health, respectively, compared to adults with salaries that covered expenses and who commuted passively (car, bus, etc.) to their main activity (Table 2).

On health issues, adults who rarely performed physical exercises had a 2.40 (CI95\% 1.14-2.12) chance of perceived negative health compared to those who regularly exercised. Also, individuals who reported not practicing healthy eating were $80 \%$ more likely to report negative perceptions of health compared to those who did (Table 2).

Also, people dissatisfied with the health service used presented a 1.29 (CI95\% 1.27-2.23) more chance of owning negative self-rated health, respectively, compared to people satisfied with the health service used (Table 2).

Finally, when comparing the cities of each Brazilian region, comparing with Goiânia (Central-West), the cities of Florianópolis (South) $(\mathrm{OR}=1.36$; CI95\% 1.06-1.75), Vitória (Southeast) $(\mathrm{OR}=1.52$; CI95\% $1.20-1.94)$ and João Pessoa (Northeast) $(\mathrm{OR}=2.19$; CI95\% 1.72-2.79) had a greater chance of negative self-rated health (Table 2).

\section{Discussion}

The present study sought to investigate factors associated with negative self-rated health in Brazilian adults. The results showed that one-third of the adults in the sample $(n=1,644)$ had negative self-rated health. A higher chance of presenting negative self-rated health's was found in Brazilian adults who did not have income that covered their expenses, who did not work and were not seeking employment, who were actively moving to their primary occupation, who rarely practiced physical exercises and were dissatisfied with the health service.

Firstly, it should emphasize that self-rated health considers various aspects of health, both subjective and objective, combined within the perceptual structure of the individual respondent $^{22}$ and is influenced by individual, social ${ }^{23}$, cultural, and environmental circumstances. Thus, the self-rated health is an active cognitive process that, according to the theoretical model of Jylhä ${ }^{4}$, has three steps for decision making in the "choice" of "my health". First, recognize the meaning of health and identify the components 
Table 2. Binary logistic regression for negative health perception (fair, poor and very poor) and associated factors in the Brazilian adult population, 2017, $\mathrm{n}=5,259$.

\begin{tabular}{|c|c|c|c|c|}
\hline \multirow{2}{*}{ Variables } & \multicolumn{2}{|c|}{ Non-adjusted analysis } & \multicolumn{2}{|c|}{ Adjusted analysis } \\
\hline & OR (CI95\%) & $\mathbf{p}$ & OR (CI95\%) & $\mathbf{p}$ \\
\hline \multicolumn{5}{|l|}{ Income } \\
\hline Low & 1 & & \multicolumn{2}{|l|}{ excluded } \\
\hline Medium & $1.01(0.87-1.17)$ & 0.900 & & \\
\hline High & $1.09(0.93-1.27)$ & 0.284 & & \\
\hline \multicolumn{5}{|l|}{ Air quality } \\
\hline Good & 1 & & 1 & \\
\hline Regular & $1.38(1.21-1.58)$ & $<0.001$ & $1.47(1.25-1.74)$ & $<0.001$ \\
\hline Bad & $1.45(1.24-1.69)$ & $<0.001$ & $1.65(1.36-2.01)$ & $<0.001$ \\
\hline \multicolumn{5}{|l|}{ Public spaces for leisure } \\
\hline It has & 1 & & 1 & \\
\hline Does not have & $1.38(1.22-1.56)$ & $<0.001$ & $1.18(1.01-1.37)$ & 0.036 \\
\hline \multicolumn{5}{|l|}{ Trees in the neighborhood } \\
\hline Many & 1 & & 1 & \\
\hline Few & $1.26(1.11-1.42)$ & $<0.001$ & $1.03(0.89-1.19)$ & 0.720 \\
\hline \multicolumn{5}{|l|}{ Gender } \\
\hline Male & 1 & & 1 & \\
\hline Female & $1.28(1.14-1.44)$ & $<0.001$ & $1.09(0.94-1.25)$ & 0.260 \\
\hline \multicolumn{5}{|l|}{ Age group } \\
\hline 18 to 34 years & 1 & & 1 & \\
\hline 35 to 59 years & $1.41(1.23-1.61)$ & $<0.001$ & $1.22(1.05-1.43)$ & 0.012 \\
\hline More than 59 years & $2.68(2.28-3.16)$ & $<0.001$ & $2.32(1.87-2.87)$ & $<0.001$ \\
\hline \multicolumn{5}{|l|}{ Education } \\
\hline Basic & 1 & & 1 & \\
\hline High School & $1.12(0.97-1.29)$ & 0.118 & $1.13(0.96-1.33)$ & 0.140 \\
\hline Superior/Post & $1.09(0.92-1.28)$ & 0.312 & $1.21(0.99-1.46)$ & 0.059 \\
\hline \multicolumn{5}{|l|}{ Occupation } \\
\hline Working & 1 & & 1 & \\
\hline Looking for a job & $1.26(1.04-1.53)$ & 0.021 & $1.04(0.80-1.29)$ & 0.901 \\
\hline Neither & $1.73(1.51-1.97)$ & $<0.001$ & $1.31(1.10-1.56)$ & 0.002 \\
\hline
\end{tabular}

that should be taken into account about "my health", then know how these components should be taken into account, for example, by comparison with reference groups, previous experiences of health or expectation of health development, being these positive or negative. Finally, it must define the position in the scale that best defines the state of health in an intuitive or consciously reflective way.

Thus, considering the conception and construction of self-rated health and its influences, among the behavioral factors, the relation between health and employment stands out, which has been evidenced in research ${ }^{24-26}$ and worsening in countries with a wide socioeconomic dispari$\mathrm{ty}^{27}$, which is the case of Brazil (Gini Index 0.515).
For Giattiet al. ${ }^{25}$, unemployment may result in negative health in different ways. In regions with a better economic situation, social impacts, such as insecurity, low control, and loss of self-esteem, are more relevant, while the impact on the absolute financial is more significant in areas of residence with material deprivation.

The relationship between unemployment and health is mediated by psychosocial, behavioral, and physiological factors. This stressful event can affect health by emotional stress related to the meaning of work and uncertainties about the future, loss of self-esteem, identity, and sense of belonging. Also, financial deprivation and the diminished capacity to meet basic needs aggravate the relationship with health ${ }^{25}$. This situation 
Table 2. Binary logistic regression for negative health perception (fair, poor and very poor) and associated factors in the Brazilian adult population, 2017, $\mathrm{n}=5,259$.

\begin{tabular}{|c|c|c|c|c|}
\hline \multirow{2}{*}{ Variables } & \multicolumn{2}{|c|}{ Non-adjusted analysis } & \multicolumn{2}{|c|}{ Adjusted analysis } \\
\hline & OR (CI95\%) & p & OR (CI95\%) & $\mathbf{p}$ \\
\hline \multicolumn{5}{|l|}{ Commuting time } \\
\hline Below 19 min & 1 & & 1 & \\
\hline From 20 to $29 \mathrm{~min}$ & $1.09(0.93-1.28)$ & 0.310 & $1.14(0.94-1.38)$ & 0.182 \\
\hline Above $30 \mathrm{~min}$ & $1.26(1.10-1.46)$ & 0.001 & $1.31(1.10-1.55)$ & 0.002 \\
\hline \multicolumn{5}{|l|}{ Commuting type } \\
\hline Passive & 1 & & 1 & \\
\hline Active & $1.41(1.23-1.62)$ & $<0.001$ & $1.36(1.14-1.62)$ & 0.001 \\
\hline \multicolumn{5}{|l|}{ Salary covers expenses } \\
\hline Yes & 1 & & 1 & \\
\hline No & $2.52(2.21-2.86)$ & $<0.001$ & $1.73(1.47-2.02)$ & $<0.001$ \\
\hline \multicolumn{5}{|l|}{ Practice of physical exercise } \\
\hline Little & $3.36(2.91-3.89)$ & $<0.001$ & $2.40(2.01-2.86)$ & $<0.001$ \\
\hline Regular & $1.77(1.50-2.08)$ & $<0.001$ & $1.52(1.26-1.84)$ & $<0.001$ \\
\hline Very & 1 & & 1 & \\
\hline \multicolumn{5}{|l|}{ Healthy eating } \\
\hline Does not perform & $2.40(2.06-2.80)$ & $<0.001$ & $1.80(1.48-2.18)$ & $<0.001$ \\
\hline Sometimes & $1.60(1.39-1.83)$ & $<0.001$ & $1.50(1.27-1.77)$ & $<0.001$ \\
\hline Perform & 1 & & 1 & \\
\hline \multicolumn{5}{|l|}{ Satisfaction with health services } \\
\hline Satisfied & 1 & & 1 & \\
\hline Neither satisfied nor dissatisfied & $0.98(0.85-1.14)$ & 0.829 & $0.97(0.81-1.15)$ & 0.717 \\
\hline Dissatisfied & $1.35(1.18-1.56)$ & $<0.001$ & $1.29(1.10-1.53)$ & 0.002 \\
\hline \multicolumn{5}{|l|}{ Cities } \\
\hline Goiânia & 1 & & 1 & \\
\hline Palmas & $1.43(1.18-1.74)$ & $<0.001$ & $1.14(0.90-1.46)$ & 0.280 \\
\hline Florianópolis & $1.10(0.90-1.35)$ & 0.335 & $1.36(1.06-1.75)$ & 0.015 \\
\hline Vitória & $1.57(1.30-1.91)$ & $<0.001$ & $1.52(1.20-1.94)$ & 0.001 \\
\hline João Pessoa & $2.48(2.05-3.00)$ & $<0.001$ & $2.19(1.72-2.79)$ & $<0.001$ \\
\hline
\end{tabular}

Source: Elaborated by the authors.

may corroborate the association of negative perceptions of health and family income that do not satisfactorily cover expenses.

Thus, even with the contradictory result of previous studies ${ }^{11,16,28}$, in this case, the non-association of negative self-rated health with the socioeconomic level (income), proposes a new perspective in the current research, that is, the use of the variable "family income or income covers (or not) expenses", which resulted in an association with self-rated health. This result leads to the need to deepen the analysis of the associations between the economic level of income and health in the sense of also considering how much the Brazilian adult's salary can finance their expenses and not only the income itself. This perspective implies a problematic resulting from the precarious management of the personal finances of Brazilians, even if the difficulty in paying the bills is not a problem exclusively for the Brazilian with low socioeconomic status. Corroborating this, a study with almost 400 thousand Brazilians has identified that multiple inequitiesare much more significant than income inequality ${ }^{29}$, thus demonstrating the importance of other factors, besides income, on Brazilian inequality.

Besides, negative self-rated health was also associated with the rare practice of physical exercises. In general, the physical benefits of physical activity are well documented to prevent some diseases such as diabetes mellitus ${ }^{30,31}$, cardiovascular diseases ${ }^{32,33}$, and even mortality prevention ${ }^{34}$. Now, for a better understanding of the action of physical exercise on self-rated health, some hypotheses have been primarily carried out and tested throughout history. Psychological hypoth- 
eses were proposed to explain the relationship between physical activity and mental health, such as the hypothesis of distraction ${ }^{35}$, self-efficacy ${ }^{36}$, and social interaction ${ }^{37}$. Also, physiological hypotheses based on monoamines ${ }^{35,37}$ and endorphins $s^{35,37,38}$ were also designed. However, it seems that a psychobiological model, involving the psychological and physiological hypotheses, is the most coherent ${ }^{39}$. Thus, it seems that the physical and mental benefits of physical exercise mediate its relation toself-rated health.

Contrary to the findings of Berglund et al. ${ }^{40}$, active commuting to work or study was associated with a higher chance of negative self-rated health. Despite the benefits of active commuting, such as reducing the emission of pollutant gases ${ }^{41}$, one should reflect on the desirability of individuals to move actively, even more in a long period daily. It is assumed that adults who practice active commuting due to lack of choice have an unpleasant reality, considering moments unfavorable to walking or cycling as adverse climatic conditions. Moreover, given the difficulty and risk of Brazilian urban dislocation, it becomes more aggravating for those who study or work in outlying areas of the city. Thus, another reality can be evidenced, the impairment of the active commuting in the health of the individual, for example, by the requirement of more significantcommuting time to actively perform the commuting can imply in reducing the duration of sleep of the individual, due to the need to wake up earlier to get to work/ study on schedule ${ }^{42}$. Even so, the results still have to be interpreted with caution, as a recent meta-analysis ${ }^{43}$ has identified a decrease in mortality, cardiovascular risk, and diabetes in actively moving adults. Thus, a better definition of active commuting in terms of type, duration, intensity, and frequency, better standardization of the methods used to evaluate the active travel, and proper consideration of several confounding factors are necessary to investigate its effect on the self-rated health.In this way, it is possible that active commuting, while behavior capable of increasing the amount of daily physical activity is healthful when optional and in certain cities, but may also have other meanings in developing countries, in cities with precarious conditions of commuting and even in societies with significant cultural value of ownership of assets like automobiles.

The findings also demonstrate the association between negative self-rated health and satisfaction with health services, which was also verified in other studies ${ }^{7,44}$. The explanations for this fact permeate the lack of a diversified supply of health services in the region ${ }^{45}$ or inadequate care, which hinders the effective use of the health service and restricts the adherence of treatments, consequently worsening the individuals' self-rated health ${ }^{46}$. In order to deepen this question, Jennings et al. ${ }^{47}$ describe that experience and expectation must be combined for satisfaction with the provision of health services. The essential attitudes listed are humanized treatment, respect, education, and patience; competence, security, and trust; priority and enhancement of patient health; optimized sharing of information and efficient medical care process.Emphasizing the satisfaction with the health service can be decisive in its use ${ }^{48}$ as well, plus the proper use, with good sense by the need of the patient, the criteria for satisfaction with health services must be addressed to promote health and improve the use of this fundamental right guaranteed by the Brazilian constitution.

These problems related to the negative perception of health must be understood broadly, considering historical, political, economic, cultural and social factors, considering the need for effective responses through intersectoral actions for health promotion and State responsibility at the level social, Community and also the individual, but not only, in a reductionist way, as an individual product ${ }^{49,50}$. For Azevedo et al. ${ }^{51}$ this blaming of the individual is a behavioral view that perceives the consumption of poor quality/unhealthy food as a choice, but not as a single option for the less favored population. What clarifies us that, despite the results of the present research identify behavioral factors related to the negative perception of health, such as the rare practice of physical exercises, active commuting, and unhealthy eating, these go through socioenvironmental conditions.

As an example, around 2009, four systemic crises affected Brazil in the economic, food, environmental and energy fields in an interrelated way in its main causes and impacts, negatively affecting the reduction of poverty, inequalities and increasing the domestic cost of food, worsening the lower-income segment ${ }^{52}$. These problems required equally systemic and coordinated responses $^{52}$. Thus, a set of inter-ministerial actions and programs of the National Plan for Food and Nutritional Security (PNSAN) was elaborated, based on the increase in the rate of formal Jobs and other measures that mitigated poverty and inequality in the country, expanding access to food in poorer Brazilian layers. Yet another example, the National School Feeding Program 
(PNAE) according to its guide lines, seeks to encourage the voluntary adoption of healthy food practices and choices based on food and nutritional education in the process of teaching-learning and offering these foods in the lunch school ${ }^{53}$. Considering these long-term investments, it is necessary to pay attention to the adherence, maintenance, and monitoring of programs like these, at regional, state and municipal levels to ensure longitudinal effectiveness in the health conditions of the Brazilian population, providing the population with awareness for adherence of healthy behaviors while adjusting socioenvironmental factors to better provide these behaviors. Thus, reducing the differences in health identified in this study. It is worth mentioning that territorial initiatives with health benefits must be maintained even if political and administrative changes happen in the municipality. In this way, policies, projects, and intersectoral actions with the support of universities, local leaders, and social movements become solid and effective before the population ${ }^{54}$.

Considering the result referring to the regions studied in this research, Other discussions can contribute to contrast the different contexts, such as the deleterious effects on health in the population living in socially disadvantaged regions, which can be created during a process of development and expansion above expectations ${ }^{55}$; also the economic and social inequality caused by the non-homogeneous urban expansion between Brazilian geographic regions throughout the historical development process, the urban density that does not respect the environment and does not prioritize the quality of life of citizens ${ }^{56}$. These urbanization processes seem to be better organized geographically in cities, in the case of the current study represented by Goiânia and Palmas, created in a contemporary period, When the potential for population grow this understood, with a prediction of high demographic density, but which still guarantee access to public services, physical and social attributes in peripheral neighborhoods, valuing the equity of conditions and quality of life of the population.

Considering the results of this research and the studies in Urban Health, the need for inter-ministerial actions is evident, also as intersectoral partnerships, seeking the collaboration of civil Society and private institutions to stimulate appropriate interventions, promote health and reduce health inequalities by pathways that go beyond the scope of the health area. Also, these initiatives must be based on the foundations of good governance, which serve as one of the pillars of these intersectoral policies including the necessary participation of the community in decisions, according to the parameters and determinants that define a Healthy City ${ }^{57}$.

The study has limitations, although it was our delimitation, the results were obtained through a public opinion survey. In this way, contextual variables, such as air quality or quantity of trees in the neighborhood, do not necessarily represent the reality measured with validated instruments, but rather, based on the subjective opinion of the interview, who lives or frequents the place where he was approached, which can cause bias from the researched individual. Similarly, the results do not imply factors directly associated with the health of the Brazilian adult, since there may be differences in the ability to self-rated and summarize one's own health, due to age, education, cognitive ability and time between responses. Likewise, due to the cross-sectional design, the results do not support causal relationships.

Still, there is a need for caution when interpreting the data. Consequently, by the dimension of the work with a large number of variables, the questions were simplified to obtain a significant amount of information from each interview, instruments that were not validated, but previously used in other studies, were used. For this, the effects of the measurement bias were mitigated by the standardization of the questionnaire, which was applied in more than twenty-one countries and fifty-two cities in Latin America and the Caribbean (with appropriate adaptation/translation from Spanish to Portuguese). In addition, the information bias was also mitigated considering the standardized quality audit procedure, in which three field coordinators checked all the questionnaires and the local coordination checked $20 \%$ of the questionnaires in order to locate and correct errors. Finally, the participating cities were only Brazilian capitals in each region, thus, not representing the reality of cities in the interior.

As a strong point, the overview provided about the self-rated health and associated factors of Brazilians through the methodology carried out is highlighted. Furthermore, the selection bias was strongly reduced by the sampling method. A random sampling at specific points of data collection after geostatistical grouping in cities in all Brazilian regions provided the participation of individuals of all age groups (over 18 years), all socioeconomic levels and levels of education, thus strengthening the results found. In addition, 
this was an original delimitation, especially with Brazilian samples, considering new socioenvironmental and behavioral factors associated with the negative perception of health in a sample of healthy individuals, based on a direct opinion by face-to-face interview.

It was identified socioenvironmental and behavioral issues were associated with negative self-rated health, like the economic difficulty, not having and not looking for work, dissatisfac- tion with health services, the form of commuting, and the rare practice of physical exercises. Despite essential insights for understanding the health of Brazilian adults, further studies should investigate new contextual variables, with a view to its non-association with self-rated health. This study covers representative results that can subsidize actions of government and help qualify the public debate regarding the demands of the Brazilian capital based on public opinion.

\section{Collaborations}

GJ Ferrari Junior structured and analyzed the information, and the text's writing. CS Teixeira designed and coordinated the research work, structured and applied the field work. ÉPG Felden supported the study's design and the text's editing. The authors all read, contributed to, and agreed to submit the manuscript for publication.

\section{Funding}

This work was supported by the Inter-American Development Bank (IDB); CAIXA Social and Environmental Fund (ACF FSA CAIXA) and Coordenação de Aperfeiçoamento de Pessoal de Nível Superior - Brasil (CAPES) - Finance Code 001, provided scholarship for the first author. 


\section{References}

1. Subramanian SV, Kim D, Kawachi I. Covariation in the socioeconomic determinants of self rated health and happiness: a multivariate multilevel analysis of individuals and communities in the USA. J Epidemiol Community Heal 2005; 59(8):664-669.

2. Moor I, Spallek J, Richter M. Explaining socioeconomic inequalities in self-rated health: a systematic review of the relative contribution of material, psychosocial and behavioural factors. J Epidemiol Community Heal 2017; 71(6):565-575.

3. Idler EL, Benyamini Y. Self-rated health and mortality: a review of twenty-seven community studies. $J$ Health Soc Behav 1997; 38(1):21-37.

4. Jylhä M. What is self-rated health and why does it predict mortality? Towards a unified conceptual model. Soc Sci Med 2009; 69(3):307-316.

5. Miilunpalo S, Vuori I, Oja P, Pasanen M, Urponen H. Self-rated health status as a health measure: the predictive value of self-reported health status on the use of physician services and on mortality in the working-age population. J Clin Epidemiol 1997; 50(5):517528.

6. Bruin A, Picavet HS, Nossikov A. Health interview surveys: towards international harmonization of methods and instruments. Geneva: WHO; 1996.

7. Chen Y, While AE, Hicks A. Self rated health and associated factors among older people living alone in S hanghai. Geriatr Gerontol Int 2015; 15(4):457-464.

8. Håkansson C, Svartvik L, Lidfeldt J, Nerbrand C, Samsioe G, Scherstén B, Nilsson PM. Self-rated health in middle-aged women: Associations with sense of coherence and socioeconomic and health-related factors. Scand J Occup Ther 2003; 10(3):99-106.

9. Aguilar-Palacio I, Gil-Lacruz AI, Sánchez-Recio R, Rabanaque MJ. Self-rated health in Europe and its determinants: Does generation matter? Int J Public Health 2018; 63(2):223-232.

10. Krause N. Neighborhood deterioration and self-rated health in later life. Psychol Aging 1996; 11(2):342.

11. Meyer OL, Castro-Schilo L, Aguilar-Gaxiola S. Determinants of mental health and self-rated health: a model of socioeconomic status, neighborhood safety, and physical activity. Am J Public Health 2014; 104(9):1734-1741.

12. Schultz J, O'Brien AM, Tadesse B. Social capital and self-rated health: Results from the US 2006 social capital survey of one community. Soc Sci Med 2008; 67(4):606-617.

13. Warnoff C, Lekander M, Hemmingsson T, Sorjonen $\mathrm{K}$, Melin B, Andreasson A. Is poor self-rated health associated with low-grade inflammation in 43110 late adolescent men of the general population? A crosssectional study. BMJ Open 2016; 6(4):e009440.

14. Cau BM, Falcão J, Arnaldo C. Determinants of poor self-rated health among adults in urban Mozambique. BMC Public Health 2016; 16(1):856.

15. Onadja Y, Bignami S, Rossier C, Zunzunegui M-V. The components of self-rated health among adults in Ouagadougou, Burkina Faso. Popul Health Metr 2013; 11(1):15.
16. Cremonese C, Backes V, Olinto MTA, Dias-da-Costa JS, Pattussi MP. Neighborhood sociodemographic and environmental contexts and self-rated health among Brazilian adults: a multilevel study. Cad Saude Publica 2010; 26(12):2368-2378.

17. Meireles AL, Xavier CC, Andrade ACS, Friche AAL, Proietti FA, Caiaffa WT. Autoavaliação da saúde em adultos urbanos, percepção do ambiente físico e social e relato de comorbidades: Estudo Saúde em Beagá. Cad Saude Publica 2015; 31:120-135.

18. Sadana R, Mathers CD, Lopez AD, Murray CJL, Iburg $\mathrm{K}$. Comparative analyses of more than 50 household surveys on health status. Geneva: WHO; 2002.

19. Levine DM, Berenson ML, Stephan D. Estatística: teoria e aplicações. Rio de Janeiro: LTC; 2000.

20. Inter-American Development Bank. Emerging and Sustainable Cities Program [Internet]. 2020 [cited 2020 Jan 10]. Available from: https://www.iadb.org/ en/urban-development-and-hous.

21. Maldonado G, Greenland S. Simulation study of confounder-selection strategies. Am J Epidemiol 1993; 138(11):923-936.

22. Tissue T. Another look at self-rated health among the elderly. J Gerontol 1972; 27(1):91-94.

23. Knäuper B, Turner PA. Measuring health: improving the validity of health assessments. Qual Life Res 2003; 12(1):81-89.

24. Chola L, Alaba O. Association of neighbourhood and individual social capital, neighbourhood economic deprivation and self-rated health in South Africa-a multi-level analysis. PLoS One 2013; 8(7):e71085.

25. Giatti L, Barreto SM, César CC. Unemployment and self-rated health: neighborhood influence. Soc Sci Med 2010; 71(4):815-823.

26. Warren JR, Hoonakker P, Carayon P, Brand J. Job characteristics as mediators in SES-health relationships. Soc Sci Med 2004; 59(7):1367-1378.

27. Ataguba JE, Akazili J, McIntyre D. Socioeconomic-related health inequality in South Africa: evidence from General Household Surveys. Int J Equity Health 2011;10(1):48.

28. Fonseca SA, Blank VLG, Barros MVG, Nahas MV. Percepção de saúde e fatores associados em industriários de Santa Catarina, Brasil. Cad Saude Publica 2008; 24(3):567-576.

29. Barbosa EC, Cookson R. Multiple inequity in health care: An example from Brazil. Soc Sci Med 2019; 228:1-8.

30. Aune D, Norat T, Leitzmann M, Tonstad S, Vatten LJ. Physical activity and the risk of type 2 diabetes: a systematic review and dose-response meta-analysis. Eur J Epidemiol 2015; 30(7):529-542.

31. Smith AD, Crippa A, Woodcock J, Brage S. Physical activity and incident type 2 diabetes mellitus: a systematic review and dose-response meta-analysis of prospective cohort studies. Diabetologia 2016; 59(12):2527-2545.

32. Sattelmair J, Pertman J, Ding EL, Kohl III HW, Haskell W, Lee I-M. Dose response between physical activity and risk of coronary heart disease: a meta-analysis. Circulation 2011; 124(7):789-795. 
33. Wahid A, Manek N, Nichols M, Kelly P, Foster C, Webster P, Kaur A, Smith CF, Wilkins E, Rayner M, Roberts N, Scarborough P. Quantifying the association between physical activity and cardiovascular disease and diabetes: a systematic review and meta analysis. $J$ Am Heart Assoc 2016; 5(9):e002495.

34. Samitz G, Egger M, Zwahlen M. Domains of physical activity and all-cause mortality: systematic review and dose-response meta-analysis of cohort studies. Int $J$ Epidemiol 2011; 40(5):1382-1400.

35. Morgan WP. Psychogenic factors and exercise metabolism: a review. Med Sci Sport Exerc 1985; 17(3):309316.

36. North TC, McCullagh P, Tran ZVU. Effect of exercise on depression. Exerc Sport Sci Rev 1990; 18(1):379416.

37. Ransford CP. A role for amines in the antidepressant effect of exercise: a review. Med Sci Sports Exerc 1982; 14(1):1-10.

38. Nicoloff G, Schwenk TL. Using exercise to ward off depression. Phys Sportsmed 1995; 23(9):44-58.

39. Paluska SA, Schwenk TL. Physical activity and mental health. Sport Med 2000; 29(3):167-180.

40. Berglund E, Lytsy P, Westerling R. Active traveling and its associations with self-rated health, BMI and physical activity: a comparative study in the adult Swedish population. Int J Environ Res Public Health 2016; 13(5):455.

41. Johansson C, Lövenheim B, Schantz P, Wahlgren L, Almström P, Markstedt A, Strömgren M, Forsberg B, Sommar JN. Impacts on air pollution and health by changing commuting from car to bicycle. Sci Total Environ 2017; 584:55-63.

42. Pereira EF, Moreno C, Louzada FM. Increased commuting to school time reduces sleep duration in adolescents. Chronobiol Int 2014; 31(1):87-94.

43. Dinu M, Pagliai G, Macchi C, Sofi F. Active commuting and multiple health outcomes: a systematic review and meta-analysis. Sport Med 2019; 49(3):437452.

44. Tran BX, Nguyen LH, Nong VM, Nguyen CT. Health status and health service utilization in remote and mountainous areas in Vietnam. Health Qual Life Outcomes 2016; 14(1):85.

45. Haraldsdóttir S, Valdimarsdóttir UA, Guðmundsson S. Poorer self-rated health in residential areas with limited healthcare supply. Scand J Public Health 2014; 42(3):310-318.

46. Ruggeri M, Nosè M, Bonetto C, Cristofalo D, Lasalvia A, Salvi G, Stefani B, Malchiodi F, Tansella M. Changes and predictors of change in objective and subjective quality of life: multiwave follow-up study in community psychiatric practice. Br J Psychiatry 2005; 187(2):121-130.

47. Jennings BM, Heiner SL, Loan LA, Hemman EA, Swanson KM. What really matters to healthcare consumers. JONA 2005; 35(4):173-180.
48. Obiechina GO, Ekenedo GO. Factors affecting utilization of University health services in a tertiary institution in South-West Nigeria. Niger J Clin Pract 2013; 16(4):454-457.

49. Buss PM. Uma introdução ao conceito de promoção de saúde. In: Czeresnia D, Freitas CM. Uma introdução ao conceito de promoção da saúde. Promoção da saúde: conceitos, reflexões, tendências. Rio de Janeiro: Editora Fiocruz; 2003. p. 19-42.

50. Verdi M, Caponi S. Reflexões sobre a promoção da saúde numa perspectiva bioética. Texto Context 2005; 14(1):82-88.

51. Azevedo E, Pelicioni MCF, Westphal MF. Práticas intersetoriais nas políticas públicas de promoção de saúde. Physis 2012; 22:1333-1356.

52. Conselho Nacional de Segurança Alimentar (CONSEA). Política Nacional de Segurança Alimentar e Nutricional - Proposições do Conselho Nacional de Segurança Alimentar e Nutricional para sua elaboração [Internet]. 2009 [cited $2020 \mathrm{Fev}$ 15]. Available from: http://www4.planalto.gov.br/consea/eventos/plenari.

53. Brasil. Lei $\mathrm{n}^{\circ} 11.947$, de 16 de junho de 2009. Dispõe sobre o atendimento da alimentação escolar e do Programa Dinheiro Direto na Escola aos alunos da educação básica. Diário Oficial da União; 2009;

54. Freire MSM, Salles RPS, Sá F, Pereira RM. Mapeando iniciativas territoriais saudáveis, suas características e evidências de efetividade. Cien Saude Colet 2016; 21(6):1757-1766.

55. Proietti FA, Caiaffa WT. Fórum: o que é saúde urbana? Cad Saude Publica 2005; 21(3):940-941.

56. Caiaffa WT, Ferreira FR, Ferreira AD, Oliveira CDL, Camargos VP, Proietti FA. Saúde urbana: "a cidade é uma estranha senhora, que hoje sorri e amanhã te devora". Cien Saude Colet 2008; 13(6):1785-1796.

57. Mathias A. Cidades e Comunidades Saudáveis: participação social e desenvolvimento de políticas públicas saudáveis. In: Sperandio A, Machín DG, Fortunato MAB. Politicas Integradas em Rede e a Construção de Espaços Saudáveis: boas práticas para a Iniciativa do Rostos, Vozes e Lugares. Brasília: OPAS/OMS; 2010. p. 89.

Article submitted 29/01/2020

Approved 02/08/2020

Final version submitted 04/08/2020

Chief editors: Romeu Gomes, Antônio Augusto Moura da Silva 